\title{
PEMBUATAN PLASTIK BIODEGRADABLE DARI PATI AREN DENGAN PENAMBAHAN ALOE VERA
}

\author{
Sari Purnavita*, Wahyu Tri Utami \\ Teknik Kimia, Politeknik Katolik Mangunwijaya \\ Email : Saripurnavita@yahoo.com
}

\begin{abstract}
Abstrak
Plastik biodegradable merupakan plastik yang mudah terdegradasi atau terurai pada kondisi dan waktu tertentu yang dipengaruhi mikroorganisme berbeda dengan plastik sintetis yang tidak dapat di urai mikroorganisme.Penelitian ini bertujuan mengkaji pengaruh jumlah aloevera dan lama pencampuran pada proses pembuatan plastik biodegradable yang optimum terhadap karakteristik plastik. Variabel bebas yang digunakan yaitu lama waktu pencampuran saat proses ( 8 menit, 10 menit, 15 menit ) dan jumlah aloevera terhadap pati Aren ( 1\%, 3\%, $5 \%, 7 \%, 9 \%$ ). Variabel tetap penelitian ini yaitu tahapan proses, suhu $\left(80^{\circ} \mathrm{C}\right)$, jumlah pati aren (5 gram), jumlah gliserol $(1 \mathrm{ml})$, jumlah pelarut $(75 \mathrm{ml})$, jumlah PVA $(2,5 \mathrm{gram})$ dan kecepatan pengadukan (225rpm). Variabel terikat penelitian ini yaitu karakteristik plastik meliputi sifat mekanik (biodegradasi, ketahanan terhadap air dan ketahanan terhadap mikroba) dan fisik (ketebalan dan morfologi permukaan).Proses produksi plastik biodegradable dari pati aren dan aloevera akan dilakukan secara dua tahap yaitu 1) Pembuatan gel aloevera dan 2) Pembuatan plastik biodegradable.
\end{abstract}

Kata kunci: Aloevera, Pati Aren, Plastik Biodegradable

\section{PENDAHULUAN}

Saat ini peranan penting plastik tidak dapat di bantah lagi. Kebutuhan masyarakat pada plastik sangatlah tinggi, seperti contohnya plastik kresek untuk memudahkan membawa barang belanjaan di supermarket, bahkan kemasan makanan dan minuman saat ini banyak yang menggunakan bahan plastik seperti cup plastik, kemasan plastik dan lainnya.

Dibalik pentingnya peranan plastik dalam kehidupan masyarakat, plastik juga memberikan masalah yang cukup serius, yaitu limbah. seperti yang kita tahu, limbah plastik susah di uraikan oleh mikroba. Maka dari itu, limbah plastik semakin lama semakin menumpuk

Di indonesia pada tahun 2008, sampah plastik mencapai 5,4 juta ton per tahun. Dengan menumpuknya sampah plastik, maka hal tersebut mendorong masyarakat untuk menemukan solusinya. Saat ini penggunaan plastik ramah lingkungan semakin banyak digunakan. Plastik ramah lingkungan yang dimaksud yaitu plastik yang berbahan dari pati yang terdapat pada biomassa. Plastik ini sering disebut plastikbiodegradable. Plastik biodegradable ini hampir sama dengan plastik konvensional, namun plastik ini dapat diuraikan oleh mikroorganisme. Dengan semakin beriringnya tahun, pembuatan plastik biodegradable ini masyarakat berinovasi dengan memanfaatkan bahan organik maupun limbah organik, seperti pati aren. Pati aren dipilih karena memiliki sumber karbohidrat yang cukup tinggi sebagai sumber polimer pembuatan plastik biodgradable.

Plastik secara sederhana didefinisikan sebagai material polimer yang dapat dicetak atau dietruksi menjadi bentuk yang diinginkan dan yang mengeras setelah didinginkan atau pelarutnya diuapkan.

Klasifikasi plastik berdasarkan bahan baku dan kemampuan degradasi dibagi menjadi plastik biodegradable dan non biodegradable. Plastik non biodegradable merupakan plastik yang tidak dapat di urai oleh bakteri atau mikroorganisme.

Sedangkan Bioplastik atau plastik biodegradable merupakan plastik yang mudah terdegradasi atau terurai pada kondisi dan waktu tertentu yang dipengaruhi mikroorganisme.

Dalam pembuatan plastik biodegradable diperlukan plasticizer. Plasticizer adalah bahan organik dengan berat molekul rendah yang ditambahkan dengan maksud untuk memperlemah kekakuan dari polimer, sekaligus meningkatkan fleksibilitas dan ekstensibilitas polimer.

Pada pembuatan plastik ini juga di tambahkan adittive Lidah buaya dan PVA.Lidah buaya berkhasiat sebagai anti inflamasi, anti jamur, anti bakteri dan membantu proses regenerasi sel. Lidah buaya mengandung gugus glikosida yang merupakan gugus aminoglikosida yang bersifat antibiotik. 
PVA memiliki kekuatan tarik yang tinggi, fleksibilitas yang baik dan sifat penghalang oksigen yang baik.

Pembuatan plastik biodegradable dari bahan pati biasanya menggunakan proses gelatinasi. Gelatinisasi adalah perubahan yang terjadi pada granula pati pada waktu mengalami pembengkakan yang luar biasa dan tidak dapat kembali ke semula. (Winarno,2002).

Untuk mengetahui sifat-sifat dan karakteristik dari plastik biodegradable yang dihasilkan maka dapat di lakukan beberapa uji, antara lain uji ketebalan, uji ketahanan air, uji biodegradasi, uji morfologi.

\section{a. Uji Ketebalan}

Film yang dihasilkan diukur ketebalannya dengan menggunakan mikrometer dengan ketelitian alat $0,0001 \mathrm{~mm}$.

b. ji Ketahanan Air

Prosedur uji ketahanan air yaitu dengan menimbang berat awal sampel yang akan diuji (wo), kemudian dimasukan ke dalam wadah yang berisi akuades selama 1 menit. Sampel diangkat dari wadah yang berisi akuades dan air yang terdapat pada permukaan plastik dihilangkan dengan tisu kertas, setelah itu baru dilakukan penimbangan. Sampel dimasukkan kembali ke dalam wadah yang berisi akuades selama 1 menit. Kemudian sampel diangkat dari wadah dan ditimbang kembali. Prosedur perendaman dan penimbangan dilakukan kembali sampai diperoleh berat akhir sampel konstan (Ban., dkk, 2005). Selanjutnya air yang diserap oleh sampel dihitung melalui persamaan:

$$
\begin{aligned}
& \text { Air }(\%)=\mathrm{w}-\mathrm{wo} / \text { wo } \mathrm{x} 100 \% \\
& \text { Keterangan : } \\
& \mathrm{W}=\text { berat } \text { edible film } \text { basah } \\
& \mathrm{Wo}=\text { berat edible film kering }
\end{aligned}
$$$$
\text { Ketahanan air }=100 \text {-serap air }
$$

\section{c. Uji Biodegradasi}

Pada pengujian biodegradasi (kemampuan bioplastik dapat terurai) dilakukan dengan merendam sampel bioplastik dalam Effective Microorganism 4 (EM4) dengan cara merendam plastik yang sudah diketahui beratnya kedalam $15 \mathrm{ml}$ larutan EM4 dalam air dan di tunggu 5 hari, setelah itu timbang kembali untuk mengetahui pengurangan massanya.

\section{d. Uji Morfologi}

Uji morfologi permukaan plastik di amati dengan bantuan mikroskop dengan perbesaran $400 x$.

\section{METODOLOGI}

Penelitian ini dilakukan pada tanggal 26 oktober 2017 hingga 11 November 2017 di laboraturium Kimia Organik Akademi Kimia Industri Santo Paulus Semarang secara eksperimental dengan Rancangan Variabel yang memiliki 2 variabel bebas.

\subsection{Bahan}

Bahan yang digunakan meliputipati aren, gliserol, aquadest, gel aloevera, PVA ,dan asam sitrat.

\subsection{Alat}

Adapun alat yang digunakan yaitu magneticstirer, hot plate, beaker glass, erlenmeyer, gelas ukur,pipettetes, timbangananalitik, termometeralkohol, cetakan plastic/nampan, dan mikroskop.

\subsection{Cara Kerja}

Penelitian ini dilakukan melalui 2 tahap yaitu pembuatan gel aloevera dan pembuatan plastik.

Pembuatan gel aloe vera dengan cara daun lidah buaya dipotong pangkal daun lidah buaya sekitar satu $\mathrm{cm}$, kemudian dikuliti lidah buaya hingga melampaui bagian sel parenkim luar, kemudian dibilas lidah buaya dengan air yang mengalir beberapa kali kemudian ditiriskannya, langkah selanjutnya merendam gel lidah buaya dengan asam sitrat $10 \%$. Selanjutnya memblender gel hingga halus selama 2 menit sehingga menjadi gel aloe vera.

Pembuatan plastik biodegradable dilakukan dengan pelarut air. Pati dan air dicampurkan dengan perbandingan 1:20 dalam gelas beker. Tambahkan 20\% gliserol dari jumlah bahan. Tambahkan larutan PVA sebanyak 2,5 gram dan tambahkan pula aloevera dengan jumlah sesuai variabel yang telah di tentukan $(2 \%, 3 \%, 5 \%$, $7 \%, 9 \%$ ). Campuran dipanaskan pada suhu $80^{\circ} \mathrm{C}$ selama 8 menit, 10 menit, 15 menit (sesuai variabel) sambil terus diaduk dengan kecepatan $225 \mathrm{rpm}$. Larutan dituangkan sebanyak ke dalam cetakan dan diratakan, lalu diletakkan dalam oven pada suhu $60^{\circ} \mathrm{C}$ selama 24 jam. Analisa yang digunakan Rancangan Acak Lengkap / RAL.

\section{HASIL DAN PEMBAHASAN}

\subsection{Ketahanan Air}

Pada percobaan ini didapatkan hasil pada variabel waktu 8 menit didapatkan optimal di penambahan aloe vera sebanyak $5 \%$ yaitu sebesar $64,61 \%$. Pada 10 menit pencampuran di 
dapatkan yang optimal dengan penambahan aloevera $2 \%$ yaitu $68,25 \%$. Sedangkan pada waktu pencampuran selama 15 menit didapatkan ketahanan air yang optimal pada penambahan aloevera sebesar 9\% yaitu 50,48\%. Dengan data diatas dapat disimpulkan bahwa terbaik pada penambahan aloe vera sebanyak $2 \%$ dengan lama waktu pencampuran 10 menit, hal ini dapat dilihat pada Gambar 1.

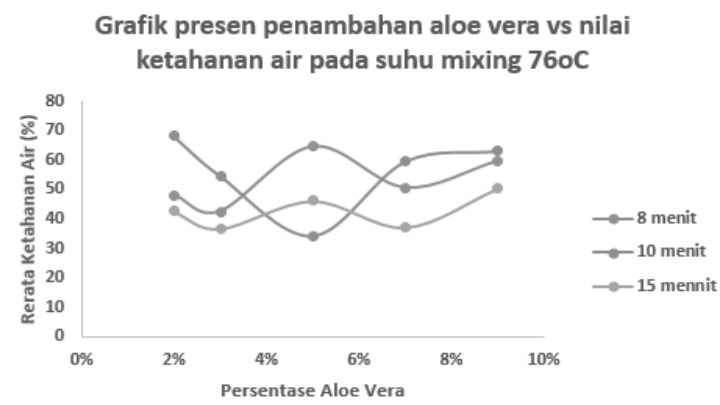

\section{Gambar 1. Gambar Grafik Persen Penambahan Aloe Vera Versus Nilai Ketahanan Air}

Berdasarkan grafik Gambar 1 di atas dan perhitungan menggunakan Rancangan Acak Lengkap, dapat di ketahui bahwa penambahan aloevera dan lamanya pencampuran tidak berpengaruh sangat nyata terhadap ketahanan air plastik biodegradable. Menurut hasil penelitian Pamilia (2014) ketahanan air dapat di pengaruhi oleh lama pengadukan, dimana jika semakin lama pengadukan maka sebaran gliserol semakin rata sehingga permukaan film plastik yang halus dan gelembung yang semakin berkurang tapi rongga dari permukaan film plastik yang semakin membesar. Semakin banyak rongga menyebabkan serapan air semakin tinggi dan ketahanan air semakin rendah. Hal ini dapat di lihat grafik ketahanan air di atas, dimana semakin lama pengadukan maka ketahanan air semakin rendah.

\subsection{Ketebalan plastik}

Penambahan aloe vera $2 \%$ pengadukan 10 menit memiliki nilai ketebalan plastik sebesar 3,5 $\mathrm{mm}$ sedangkan pada penambahan aloe vera $2 \%$ pengadukan 15 menit memiliki nilai plastik sebesar $7 \mathrm{~mm}$. Jika di tinjau dari banyaknya total padatan, pada pada jumlah presentase aloe vera $7 \%$ lebih tebal $(1,25 \mathrm{~mm})$ dibandingkan $5 \%(0,9$ $\mathrm{mm}$ ) dengan lama pengadukan yang sama hal ini dapat dilihat pada Gambar 2.

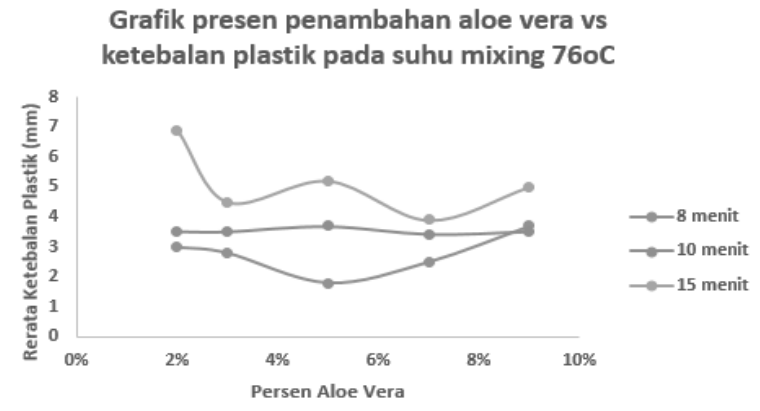

\section{Gambar 2. Gambar Grafik Persen Penambahan Aloe Vera Versus Ketebalan Plastik}

Pada Gambar 2 sesuai dengan penelitian yang telah dilakukan Sumarto (2008) ketebalan film dipengaruhi oleh banyaknya total padatan dalam larutan dan ketebalan (tinggi) cetakan. Pada tabel dan grafik diatas dapat di simpulkan bahwa penambahan aloe vera dan lama pencampuran berpengaruh terhadap ketebalan plastik. Semakin tinggi total padatan di dalam campuran maka ketebalan plastik juga semakin tinggi. Begitu pula semakin lama pencampuran akan semakin cepat tergelatinasi sehingga campuran semakin kental. Jika campuran semakin kental maka penyebaran campuran semakin susah merata dan ketebalan plastik semakin besar.

\subsection{Uji Biodegradasi}

Dari hasil penelitian ini di dapatkan hasil sesuai dengan teori yang ada, dimana semakin lama mixing time semakin tidak mudah terurai. Pada penelitian ini didapatkan hasil yang optimal pada penambahan aloevera sebesar $7 \%$ dengan waktu mixing selama 8 menit yaitu skor 5 , yang dapat dilihat pada Gambar 3.

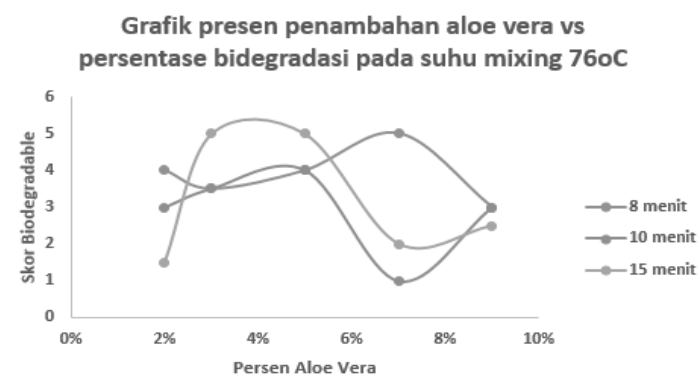

\section{Gambar 3. Gambar Grafik Persen Penambahan Aloe Vera Versus Skor Biodegradasi}

Hasil Uji biodegradasi seperti yang ditunjukkan pada Gambar 3 ini dilakukan menggunakan air sebagai aktifator EM4, sehingga data diatas tidak valid untuk 
perhitungan rancangan acak lengkap. Sehubungan dengan itu, hasil biodegradasi di tunjukan dengan skor 0 sampai 10. Skor 0 menunjukan plastik tidak terdegradasi dan semakin tinggi skor maka plastik semakin terdegradasi sempurna.

Lidah buaya kaya akan kandungan zat-zat seperti enzim, asamamino, mineral, vitamin, poli $\mathrm{s}$ akarida dan komponen lain yang sangat bermanfaat. Selain itu, lidah buaya berkhasiat sebagai anti inflamasi, anti jamur, anti bakteri.

Menurut Teresya (2016) lidah buaya menghambat Staphylococcus sp dan Escherichia Coli. Namun pada EM4 mengandung lactobacillus sp, saccharomyces sp, actinomycetes sp sehingga pada penambahan lidah buaya tidak menghambat biodegradasi plastik ini. Menurut Argo (2011) semakin lama pengadukan semakin kuat pula ikatan-ikatan yang terjadi dalam film bioplastik, maka semakin sulit untuk diurai. Pada penambahan aloe vera sebanyak $2 \%$ dengan pencampuran selama 8 menit, 10 menit, 15 menit berturut-turut adalah 4 , 3 , dan 1.5 .

\subsection{Uji Morfologi Plastik}

Permukaan olastik juga diperlukan uji morfologi. Uji Morfologi plastik dapat dilihat pada Gambar 4.

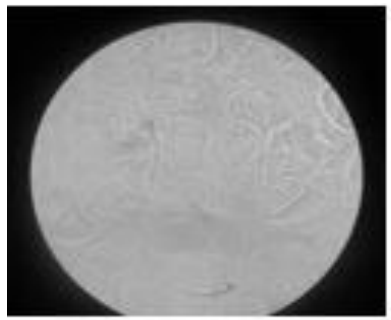

(1)

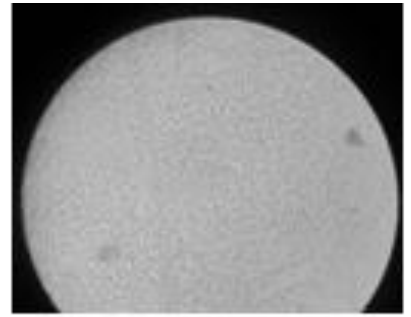

(2)

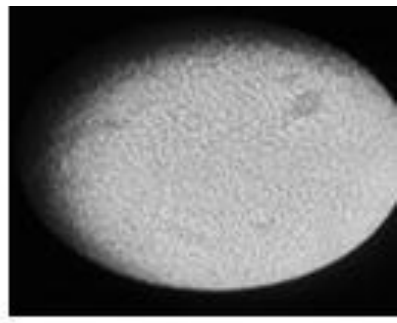

(3)

Gambar 4. Gambar Morfologi Permukaan Plastik

Gambar 4 merupakan morfologi plastik dengan penambahan aloevera $2 \%$. (a) morfologi plastik dengan lama pencampuran 8 menit. (b) morfologi plastik dengan lama pencampuran 10 menit. (c) morfologi plastik dengan lama pencampuran 15 menit. Menurut Pamilia (2014) morfologi plastik di pengaruhi oleh lama pengadukan. Semakin lama pengadukan maka penyebaran gliserol semakin merata sehingga permukaan semakin halus yang di tandai gelembung yang semakin sedikit danrongga yang semakin lebar atau banyak. Hasil morfologi permukaan plastik yang optimum didapatkan pada penambahan aloe vera sebesar $2 \%$ dengan lama pencampuran 15 menit.Maka disimpulkan hasil percobaan ini sesuai dengan teori.

\section{KESIMPULAN}

Dari hasil penelitian dapat diambil kesimpulan bahwa jumlah aloevera dan lama pengadukan tidak berpengaruh terhadap ketahanan air dan lamanya biodegradasi plastik. Namun jumlah aloevera dan lama pengadukan mempengaruhi ketebalan plastik. Lama pengadukan pencampuran mempengaruhi morfologi plastik.

\section{UCAPAN TERIMA KASIH}

Ucapan terimakasih kami ucapkan kepada Direktur Polteka Mangunwijaya dan Ketua LPPM atas dukungan dana dan fasilitas yang telah diberikan.

\section{DAFTAR PUSTAKA}

Argo, (2011), Pengaruh Penambahan 1,4Butanadiol dan Polietilen Glikol (PEG) 1000 terhadap Kemudahan Biodegradasi Bioplastik dari Biji Nangka (Artocarpus heterophyllus), Eksakta: Jurnal Imu-Ilmu MIPA, p. ISSN: 1411-1047 e. ISSN: 25032364 Hal:116

Ban, W., Song, J., Argyropoulos, D. S. \& Lucia L. A., (2005), Improving the physical and chemical functionally of Starch - Derived Films with Biopolymers, Journal of AppliedPolymer Science, 100: 2542-2548.

Teresya, P., (2016), Uji Daya Hambat Ekstrak Daun Lidah Buaya (Aloe Vera L.) Terhadap Bakteri Escherichia Coli Dan Staphylococcus Aureus: Review

Pamilia, (2014), Pembuatan Film Plastik Biodegredabel DariPati Jagung Dengan Penambahan Kitosan DanPemplastis Gliserol, Jurnal Teknik Kimia, No. 4, Vol. 20. Hal: $27-28$ 
Sumarto, (2000), Mempelajari Pengaruh Penambahan Asam Lemak dan Natrium Benzoat terhadap Sifat Fisik, Mekanik dan Aktifitas Antimikroba Film Edible Kitosan, Skripsi, Departemen Ilmu dan teknologi Pangan Fakultas Teknologi Pertanian Institut Pertanian Bogor

Winarno, F.G., (2002), Fisiologi Lepas Panen Produk Hortikultur, M_Brio Press. Bogor. Hal: 85. 